\title{
A Call to Revisit and Address the Histories of Bullying in Nursing Education
}

\author{
Zachary Daly \\ University of British Columbia, Vancouver, zachary.daly@ubc.ca \\ Kathy O'Flynn-Magee \\ University of British Columbia, Vancouver, kathy.oflynnmagee@ubc.ca \\ Patricia Rodney \\ University of British Columbia, Vancouver, paddy.rodney@ubc.ca
}

Follow this and additional works at: https://qane-afi.casn.ca/journal

Part of the Other Nursing Commons

\section{Recommended Citation}

Daly, Zachary; O'Flynn-Magee, Kathy; and Rodney, Patricia (2020) "A Call to Revisit and Address the Histories of Bullying in Nursing Education," Quality Advancement in Nursing Education - Avancées en formation infirmière: Vol. 6: Iss. 3, Article 9.

DOI: https://doi.org/10.17483/2368-6669.1249

This Article is brought to you for free and open access by Quality Advancement in Nursing Education - Avancées en formation infirmière. It has been accepted for inclusion in Quality Advancement in Nursing Education - Avancées en formation infirmière by an authorized editor of Quality Advancement in Nursing Education - Avancées en formation infirmière. 
Forty years ago, one of the authors was regularly asked as a nursing student if she was "born stupid or had she taken a course in it?" At the time, in the mid-1970s in an inner city hospital, the author did not take the comment too seriously because as soon as the secular nursing sister finished with the author, she was off to say the same thing to another student. Lessons learned were that it was not to be taken personally, it had a certain wit, and no real harm was done. When Canadian nursing students hear this story in 2020, they are dismayed that someone would speak to a student in that way and that the student would be expected to tolerate it.

In this paper, we reflect on the history of bullying in nursing, and more specifically nursing education, with particular attention to the Canadian context. Knowing where we have been to understand where we are and where we should be going is surely the legacy that nursing's rich history can give us. Yet, given the still prevalent phrase that nurses are "eating their young," it is clear that we still have lessons to learn and to act upon. Indeed, Adams and Maykut (2015) maintained that bullying in nursing has become more visible and even more rampant over the years. Ignoring its existence or downplaying its impact are not options, they say, and addressing this dark side of nursing is imperative.

We argue that to fully tackle the issue of the bullying experienced by nurses, and more specifically student nurses, it is important to critically examine its historical trajectory and roots, as we believe that contemporary issues of bullying are directly related to their historical antecedents. Furthermore, we suggest that understanding the nature of this issue within Canadian nursing practice will likely require research attuned to Canadian nursing's particular context and history. This process includes appreciating the influences and blending of Indigenous healing traditions, the francophone Catholic nursing tradition, the anglophone apprenticeship system (Wytenbroek \& Vandenberg, 2017), and more recently the experiences of internationally educated nurses (IENs), many of whom have faced barriers in Canadian practice (Prendergast, 2014).

As bullying is so closely tied to power, and power imbalances, we believe that scholarship on this issue must take historical and contemporary power dynamics into account, and also recognize how these dynamics may impact different groups in the profession, as well as our relationships with other health care professions. Thus, our scholarship is informed by relational and critical power perspectives. Along with others addressing nursing and ethics, we are working to promote the relational ethical obligations that ought to support nursing practice at individual, organizational, regional, and national/international levels. These obligations include, for example, commitments to human dignity, equity, and the socially just allocation of resources (Canadian Nurses Association [CNA], 2017; Doane \& Varcoe, 2013; Kenny et al., 2010; Wiskow et al., 2010). We see the prevention and amelioration of bullying in our profession at all levels as a prerequisite to having the capacity to fulfil such relational obligations. A relational approach to understanding bullying fits well into the model of bullying in nursing proposed by Hutchinson et al. (2010). This model is helpful in that it situates acts of bullying within larger organizational contexts, with factors such as "informal organizational alliances," "organizational tolerance and reward" and "misuse of legitimate authority, processes \& procedures" leading to bullying, which in turn has downstream consequences. While it was envisioned for the understanding of organizational factors related to bullying in working environments, we would propose a slight extension of the model, in that we suggest that it can be helpful for historical analysis. In particular, the model suggests a pathway through which organizational tolerance, leading to acts of bullying, can in turn lead to a normalization of bullying, setting up a cycle or loop that can act across time. Thus, while present manifestations of bullying are the result of present organizational contexts, they are also in part a 
result of historical forms of bullying that may have been tolerated, rewarded, or ignored. The implication is that to address bullying today, we must intentionally address acts of bullying when they arise and also address their historical contexts. Overall, it is our position that there is a need for a deeper analysis of bullying and its history in early and more contemporary nursing education in Canada, which also requires that we clarify what is actually meant by bullying.

\section{Addressing the Issue of Terminology}

Griffin (2004) and Griffin and Clark (2014) emphasized the importance of naming bullying for what it is before it can be addressed. Although there is no universal definition of bullying, having a working definition is of great importance when unpacking this complex phenomenon because clearly identifying the behaviour is prerequisite to dealing with it. Research in the field of organizational behaviour and workplace aggression makes use of a variety of theoretical constructs such as social undermining, emotional abuse, emotional tyranny, interpersonal mistreatment, and workplace bullying, with newer terms evolving over time (Keashly et al., 2020). This "proliferation of constructs" has led some, such as Hershcovis (2011), to argue for a reexamination of terms and how they are assessed, particularly given the overlap between many of them. Further complicating matters, Neall and Tuckey (2014) have pointed out that the use of different constructs may vary by the geographic region in which research takes place. Even within nursing literature, there are numerous terms and definitions related to bullying (Gillespie et al., 2017; Seibel, 2014; Vessey et al., 2011), including horizontal violence, mobbing, and incivility (Clarke et al., 2012). This diversity compromises the clarity and transparency of bullying as a phenomenon, making it difficult to recognize, acknowledge, address, and report. We have found that while some of these terms differ from each other in important ways, the wide variety makes attempts to understand and even locate past scholarship related to bullying in nursing, and more specifically of nursing students, more difficult.

Although bullying is a commonly used term, it can be understood in disparate ways. In particular, there appear to be two notable tensions in the nursing literature in understanding behaviours such as bullying or not: first is the importance of intention to bully versus unintentional bullying; second is whether bullying is characterized exclusively by an ongoing pattern of behaviour or whether it can be a single incident (O'Flynn-Magee et al., 2020). We take a broad view and believe that bullying can include any or all of the above, rather than insisting on the presence of intention and repetition. Drawing on a Canadian workplace regulatory definition of bullying and harassment from British Columbia's WorkSafe BC (2013), we expand their focus on workers to include students:

(a) includes any inappropriate conduct or comment by a person towards a worker [or student] that the person knew or reasonably ought to have known would cause that worker [or student] to be humiliated or intimidated, but

(b) excludes any reasonable action taken by an employer or [a] supervisor relating to the management and direction of workers [or students] or the place of employment. (section 3 , The $A c t$ )

The statement above that bullying "excludes any reasonable action taken by an employer or [a] supervisor" is particularly salient for professional groups such as nursing. It has long been recognized that clinical evaluation can elicit strong feelings of anxiety or fear among nursing students (Burnstein, 1995). Students may even equate performance critiques with bullying, depending on how it is delivered (Seibel, 2014). In a Canadian study of nursing students, the most 
commonly reported source of bullying was clinical instructors, even more so than staff nurses (Clarke et al., 2012). Because of this, the WorkSafe BC (2013) definition of bullying is particularly useful in educational contexts such as nursing, as it would exclude the provision of constructive feedback to students but still include feedback that is given in a way that "the person knew or reasonably ought to have known would cause that [student] to be humiliated or intimidated" (O'Flynn-Magee et al., 2020). We also acknowledge that this definition is a wider conceptualization of bullying than seen elsewhere, as theoretical definitions of bullying in organizational behaviour literature often emphasise the importance of a behaviour being repeated or ongoing to be considered bullying, compared to other constructs such as incivility or social undermining (Hershcovis, 2011; Keashly et al., 2020). We argue that casting a wider net, as we do here, facilitates the unearthing of relevant information, and helps to avoid some of the pitfalls of terminology alluded to above, and that this approach will be particularly useful when looking at historical records. Finally, while we take the position that bullying is a form of violence, and can take multiple forms, we also understand that not all forms of violence are necessarily best understood through the prism of bullying.

\section{The Magnitude and Impact of Bullying in Practice and Education}

The ongoing existence of bullying is not only an issue for nurses in practice (Canadian Nurses Association \& Canadian Federation of Nurses Unions, 2015a, 2015b; Clarke et al., 2012; Houshmand et al., 2012; Vessey et al., 2009) but is also acknowledged as a serious concern in current nursing education (Birks et al., 2018; Bowllan, 2015; Budden et al., 2017; Clarke et al., 2012; Darbyshire et al., 2019; Fehr \& Seibel, 2016; Gillespie et al., 2017; Griffin, 2004; Jack et al., 2018; Jackson et al., 2011; Palaz, 2013; Seibel, 2014; Seibel \& Fehr, 2018; Tee et al., 2016; Thomas, 2010; Thomas \& Burk, 2009). More recently, it has come to light that not only is experiencing bullying an issue but witnessing it is also problematic (Báez-León et al., 2016; MacCurtain et al., 2018). While in this paper we focus on the experience of students, it is important to note that nursing faculty may also experience bullying or incivility (Gazza, 2009; Small et al., 2019).

Bullying in nursing practice has been discussed in numerous Canadian contexts. As an example, $89 \%$ of surveyed nursing students in a Canadian school of nursing reported experiencing bullying (Clarke et al., 2012). A 2019 study of Canadian nursing students likewise found that 87\% felt that "incivility" in nursing education was a problem (Small et al., 2019). Bishop (2004) conducted a qualitative analysis of the experiences of practising nurses while Hunt and Marini (2012) looked specifically at the experiences of clinical instructors. While not focused on nursing education, Eggertson (2011) also raised the issue of bullying and shared numerous stories from practice.

A 2006 study of the experiences of Indigenous nursing students at two Canadian schools of nursing highlighted the ongoing experiences of racism by students within schools and hospitals (Martin \& Kipling, 2006). Vukic et al. (2012) explored the life experiences of Indigenous nurses in Atlantic Canada and found that participants regularly experienced racism at the personal and systemic levels, as well as witnessing racism directed at Indigenous patients in the health care setting. While not focused on the experiences of students, Najja Nwofia Modibo (2004) explored the experiences of 15 female African-Canadian nurses in hospitals in Ontario in the late 1980s to the mid-1990s. Modibo's findings revealed ongoing systemic racism evidenced by the assignment of African-Canadian nurses to positions in "heavy" areas such as chronic care; disadvantages compared to White female immigrant nurses; their being forced to wear visibly unique uniforms 
designed to highlight social status and difference; an assumption that their preparation was lesser than; intense scrutiny by supervisors and peers; a heavier workload than that given to others; and apparent blocks to moving upward on their career trajectory. This study came at a time when the Ontario Human Rights Commission supported a claim of systemic racism by nurses in one hospital in Ontario, resulting in financial compensation for nurses and a directive to initiate anti-racist processes in the offending hospital (Modibo, 2004). Linking this to bullying, we agree with Allan et al.'s (2009) claim that there is a certain type of bullying that is racist in nature. These authors argued for the use of the term "racist bullying" when the bullying behaviours are sparked by racism. They also contend that this form of bullying must be managed as a type of racism.

In addition to adverse emotional and performance outcomes for those affected by bullying, of particular concern are the links between bullying and reduced patient safety (Bowllan, 2015; Budden et al., 2017; Tee et al., 2016). Bullying has also been linked to newly graduated nurses' attrition (MacKusick \& Minick, 2010). Further, there is the possibility that targets of bullying may precipitate their bullying others (Gheorghiu, 2014; Tee et al., 2016), thus normalizing a highly problematic behavioural cycle into future practice. We argue that tolerance and normalizing of bullying over time is one way that the history of bullying in nursing has influenced what is currently happening for nurses and nursing students in their everyday practices; the model proposed by Hutchinson et al. (2010) lays out a pathway from "organizational tolerance and reward" to "bullying acts" to "normalization of bullying in work teams." Regardless of its ultimate origins, if left unaddressed, bullying in nursing education risks becoming a self-perpetuating phenomenon, as "each new generation of nurses will continue to be socialized into negative practices" (Randle, 2003, p. 395). The implications are that bullying must be addressed not only in the health care setting but also in the nursing academy and that echoes of historical bullying can play out in contemporary practice.

\section{A Brief History of Bullying in Nursing Education}

Nelson (2009) described a "historical amnesia" that is often associated with early nursing work that is neither valued nor built upon. Yet, ignoring or forgetting our history does not allow us to move forward - that is, to learn from the "blunders of those who came before us," view history in context, or draw on intergenerational wisdom to shape contemporary nursing practice and education (Nelson, 2009, p. 787). Holme (2015) emphasized the importance of reviewing existing history and the gaps in history and cautions us to unpack history within the context in which it occurred so that unfair and inaccurate comparisons can be avoided. Nelson and Gordon (2004) described unfair comparisons in nursing as problematic because they can result in a legacy of intergenerational biases. Indeed, it is wise to remember that history is never solely factual or neutral; rather, it is always remembered through a particular lens, perspective, or viewpoint (Linsley et al., 2019). Describing the "pedagogy of remembrance" as teaching, or facilitating learning about, history, Linsley et al. (2019, p. 29) argued that its emphasis ought to be on generating thought-provoking and critical ideas rather than solely focusing on historical facts.

Of course, any analysis of bullying within nursing education specifically must also acknowledge the wider history of bullying in education as a whole and in the broader society. In their history of bullying in schools, Allanson et al. (2015) pointed out that while terms and attitudes have changed over time, bullying has long been a part of school systems and society. Indeed, they cited examples going back to the 1800s. However, the existence of bullying within society at large does not, in our opinion, absolve nursing of a responsibility to critically examine the existence and specific causes of bullying within our profession. 
With all of this in mind, it is salient to note that over 30 years ago Meissner (1986, p. 52) asked if nurses "eat their young" and thus cemented the use of a phrase that continues, sadly, to be relevant today. Although Meissner is credited with the phrase, the expression was already being used in 1965 at Dalhousie University in Halifax, Canada, according to Halifax RN Barb Fry (Eggertson, 2011). Szutenbach (2013) noted that bullying in nursing practice was first cited in the literature in the 1970s and 1980s, and our review uncovered a 1995 publication from Australian researchers as a first sighting in the literature of where student experiences of bullying were highlighted (Alavi \& Cattoni, 1995). In their paper, Alavi and Cattoni (1995) shared a cruel story that a nurse had heard a number of times through many versions:

A new student nurse presents for work in a ward she has not worked in before. A patient (usually elderly) has just died. One of the (usually more senior) nurses on the ward asks the student to take the dead person's observations. The student returns with either a fictitious set of readings for pulse, respiratory rate and temperature (because she has already learnt that punishment or humiliation are meted out for admitting inability in any area) or she returns distraught upon discovering the person to be dead, believing she is the first to make the discovery or, in some cases, believing she has done something to cause the death. The story is usually relayed by experienced nurses over coffee and is followed by a string of similar such stories from others. (Helen Simms, RN, as quoted in Alavi \& Cattoni, 1995, p. 346)

Despite the lack of explicit discussions of nursing student bullying in the peer-reviewed literature before Alavi and Cattoni (1995), it is still possible to find earlier references to behaviour that might be understood by a modern reader as bullying of students. One example is the following statement from an early nurse education leader, Ethel Johns, which was published in 1948 and described the experiences of student nurses enrolled at the University of British Columbia during the early years of the program, when university education in nursing was beginning in Canada:

In the hospital, they were marked women and the slightest infringement of regulations was punished as though it had been a violation of the decalogue. Worst of all, they were held aloof by the hospital student nurses and were regarded as giving themselves insufferable airs. In the university, they were singled out for scorn and rebuke unless they displayed superior intelligence on all and every occasion. But there was a stubborn loyalty among these harried little groups. They carried the weight of the young enterprise on their young shoulders and they saved the day. (p. 721)

This statement is notable in several ways. First is its context. The University of British Columbia was the location of the first baccalaureate nursing program in Canada (Canadian Association of Schools of Nursing, 2012). Second, and related to the first point, is its age. The statement suggests that while dedicated discussions of bullying may not have appeared until later, behaviours that might now be understood as bullying were discussed nearly a century ago among the very roots of university nursing education in Canada.

It is also important to highlight the experiences of Indigenous Canadian nursing students. Bill and Gillis (2018) reminded us that Indigenous students were barred from admission to Canadian schools of nursing in the past, and even when they were admitted, they were subjected to other forms of discrimination. Some left Canada, instead choosing to study in the United States, where, according to Drees (2013), nursing schools were more accepting. The Canadian Association of Schools of Nursing (2012) claimed that it was not until there was increased demand 
for nurses that "racial and ethnic barriers to admission into nursing schools began to erode" ( $p$. 12). In 1989, Jean Cuthand Goodwill, then the president of Indian and Inuit Nurses of Canada, wrote of the "discrimination and lack of support in the Canadian education and health care system" (p. 118) experienced by "most members" of the organization. More broadly, Wytenbroek and Vandenberg (2017) have recently argued that Canadian nursing history has overly focused on British and French traditions, while excluding the importance of Indigenous health practitioners.

Flynn (2008) writes of the barriers to enrolment in nursing schools faced by Black Canadians, with many having to abandon their preparation or enrol in the United States, as well as the difficulties that individuals from the Caribbean had in immigrating to Canada to either practise or study nursing. As part of this, Flynn (2008) discussed the 1940 correspondence between a Black Canadian father advocating for his daughter and a Canadian nursing director, who suggested that the daughter should seek nursing education in the United States instead of Canada.

\section{Potential Origins of Bullying Within Nursing and Nursing Education}

What, then, might have been the sources of bullying within nursing and nursing education in Canada and elsewhere? In 1983, Roberts famously used the concept of oppressed group behaviour to understand the ways in which nurses interact with each other and other health care professionals. Over recent decades, nursing's bullying behaviours have been explained as reflective of gender biases and hierarchical health care power structures (Street, 1992), as well as workplace sanctions meant to promote "efficient" practices (Varcoe \& Rodney, 2002). More recently, Croft and Cash (2012) analyzed results from a 2009 survey on bullying from the British Columbia Nurses Union and Union of Psychiatric Nurses using what they termed a "postcolonial feminist lens," highlighting among other things the hierarchical nature of nursing practice.

Historically, professional hierarchies, nurses' status in those hierarchies, and power structures have all contributed to nurses' experiences of being bullied (Szutenbach, 2013). Tracing our profession's history over the last 50 years, it appears that the typical hierarchies between medicine and nursing resulted in physicians having, and using, power over others, especially nurses. MacKintosh and Sandall (2010) drew on the work of Davies (2003), who stated that "doing dominance and doing deference have been part and parcel of how nursing and medicine were historically constructed in relation to one another" (Davies, 2003, p. 728). Based on their analysis of health care communication in the United Kingdom, MacKintosh and Sandall (2010) emphasized how power imbalances within gendered and occupational hierarchies can create communication challenges associated with negative patient outcomes, such as "failure to rescue." Despite recent constructive changes in professional partnerships in health care overall, there is evidence to suggest that nurses still engage in bullying behaviours, not only within nursing but across health care professional groups (O'Flynn-Magee et al., 2020). Specifically, in a recent Canadian study, nurses were identified by diverse health care faculty as a source of bullying experienced by medical and other health care professional students (O'Flynn-Magee et al., 2020).

We argue that attending to individual and interpersonal factors alone are not sufficient to understand bullying. There are important sociopolitical influences, such as misuse of power, structural constraints, corporatization of health care, hierarchical structures, and divisiveness within the ranks, that contribute to bullying (see, for example, Akella, 2016). As historical examples of the last point, Stanley (2019) discussed the divisions between paid and unpaid nurses in the Crimean war, divisions rooted in racism in the US civil war, and divisions based on religion in World War I. Separately, the move from hospital-based apprenticeship training to a university 
education created adversarial divisions (Alavi \& Cattoni, 1995). These divisions included diploma versus degree status. More recently, the divisions have also included the advanced practice nurse practitioner versus the registered nurse (Nelson \& Gordon, 2004). These examples illustrate the range of contexts and divisions in nursing over time. While the specific nature of these divisions has changed, their commonality lies in the devaluing of the "other," such as the belittling of traditional nursing work as domesticated (Nelson, 2009; Nelson \& Gordon, 2004). Nelson and Gordon (2004) described this lack of respect for and disowning nursing's origins as a "rhetoric of rupture" (p. 255).

Further, it has been argued that bullying in the profession may originate in the nature of nursing education itself (Weinand, 2010). In 1995, Alavi and Cattoni described "a kind of xenophobia [in academia] which identifies and differentiates true nurses as those who speak within the terms outlined in the discourse of new professionalism" (p. 348). Discussing the prevalence of horizontal violence in nursing, Baltimore (2006) argued that "the likely root of such behavior is the intense hierarchical structure of health care and academia" (p. 30). More recently, Seibel and Fehr (2018) have cautioned that doing nothing to manage bullying in nursing education leads to increased bullying in the profession.

\section{Finding our Way Forward}

As our analyses above suggest, bullying has an unfortunately long and problematic history in nursing education and nursing practice, particularly, though not only, as directed at nursing students. It is our premise that by understanding this history we are in a stronger position as individual nurses (e.g., students, faculty, new nurses, and experienced nurses) and as collectives of nurses (e.g., student associations, faculty associations, professional nursing associations, and nursing unions) to re-shape our future. Fortunately, important work is occurring nationally and internationally through diverse groups working on related policy initiatives.

In Canada, for example, the last two revisions of the Canadian Nurses Association's Code of Ethics for Registered Nurses (CNA, 2008, 2017) have specifically addressed "ethical considerations in relationships with nursing students." In the most recent version, there are eight related guidelines, two of which state that "all teacher-nursing student interactions are to be in keeping with ethical nursing practice," and that "all nurses and nursing students treat each other with respect and honesty" (CNA, 2017, p. 41). And in 2015, the CNA and the Canadian Federation of Nurses Unions released a Joint Position Statement on Workplace Violence and Bullying to ameliorate and prevent the problem.

The documents we have noted above are clear in articulating the values that ought to inform relationships between nurses, nursing students, other colleagues, and those whom nurses serve. Further, the Canadian Nursing Students' Association (CNSA) affirms the importance of and adds to the policy work done by the CNA and the Canadian Federation of Nurses Unions. In 2014, the CNSA published a Position Statement on Creating an Empowering Environment for Nursing Students to Eliminate Bullying in the Nursing Profession (Gheorghiu et al., 2014). In this document, the CNSA noted that "it is important to stop the cycle of bullying. The journey of accomplishing this starts with nursing students and creating an empowering and supportive environment where their experiences can be addressed" (p. 1). The CNSA document also pointed to the importance of developing "empowering environments where clinical instructors or supervisors advocate for their students, and include bullying as an open topic of discussion in clinical debrief sessions" (p. 1). 
Our US nursing colleagues have also been working to address bullying. In 2015, the American Nursing Association generated a comprehensive 23-page Position Statement on Incivility, Bullying, and Workplace Violence. This document is noteworthy in its scope and policy reach, including, for example, sections on "Responsibilities of Registered Nurses and Employers" (p. 6); "Incivility and Bullying: Recommended Interventions" (p. 7); and "Workplace Violence: Recommended Interventions" (p. 11). Internationally, the International Council of Nurses (ICN) has a position statement, Prevention and Management of Workplace Violence (2017), that also addresses bullying. And more recently, in 2019 nursing leaders at an ICN International Workforce Forum addressing the nursing shortage claimed that "we need to implant a range of actions to foster positive and supportive working environments, including fair pay, safe staffing, professional and career development, and the absence of violence, bullying and harassment" (ICN, 2019, para. 5). Notwithstanding promising initiatives from diverse nursing organizations to address bullying, the issue persists. Indeed, the ongoing prevalence of bullying — particularly of nursing studentsemphasizes that more needs to be done.

\section{The Need to Also Look Backwards}

To strengthen and inform the forward looking initiatives chronicled above, we must also look backwards. In particular, we stress the need for further historical analyses of the underlying causes of bullying in nursing education, paying particular attention to the unique circumstances of nursing in Canada. These circumstances include the transition to university-based programs and Canada's wider colonial history and its ongoing impacts. We believe that there are unfortunate gaps in understanding, not only in terms of the timeline (especially in earlier years) but also in terms of specific voices.

As McPherson and Stuart (1994) argued, certain groups within nursing have historically been more likely to leave records, which "has often skewed the historical record toward the elite, formally trained, full-time practitioners, and has oriented the record toward the socially respectable or celebratory, leaving more marginal practitioners silent" (p. 16). Paralleling this critique, Flynn started her 2008 history of Black Canadian nurses by stating that "the paucity of historical materials on Black Canadian women does not necessarily mean the sources are unavailable," and went on to describe her use of diverse sources, such as oral interviews, immigration records, and a re-examination of existing archival sources such as yearbooks, syllabi, and conference papers to reveal this history. Such a methodology would be helpful for illuminating the history of bullying in nursing, particularly, in our opinion, when paired with a wider theoretical conception of bullying as argued for earlier in our paper. This research will also be assisted by the guidance of conceptual models, such as by Hutchinson et al. (2010), as they serve as a guide for what types of information to seek. This model would suggest that it is important not only to search for individual stories of bullying but also to critically unearth information related to workplace environments, such as "informal organizational alliances" or "misuse of legitimate authority," both of which have been identified as antecedents of bullying (Hutchinson et al., 2010). Particular attention must be paid to elucidating the stories of Indigenous nurses, IENs, and other historically marginalized groups in nursing, as well as to investigating both francophone and anglophone sources. Correcting the gaps in our understanding will require a critical re-examination of existing primary and secondary sources, and a concerted effort to seek out new sources of information that may not have been sought out previously. We believe such scholarship to be worthy in and of itself, and also suggest that scholarship highlighting and understanding our past can disrupt forms of "organizational tolerance" to bullying acting in the present day. 


\section{Conclusion}

History is a gift, if we choose to accept it. For Eavan Boland (2007), renowned Irish poet, there was "a huge rift in Ireland between the past and history. The past, she explained, was "a place of whispers, and shadows and vanishings, and that history was a story of heroes" (para. 4). Boland was not interested in history; she was interested in "what disappears into that past" (para. 6). We believe that both history and the past are needed in our study of nursing as a profession, and the past is especially relevant to avoid what Nelson (2009) has called a dangerous "historical amnesia" (p. 781).

Academic scholars Allanson et al. (2015) claimed that "we have still not heeded history in preparing for a future that we still know nothing about" (p. 35). Consequently, there is a pressing need to address the issue of bullying in nursing constructively yet also vigorously (Weinand, 2010). Numerous positive initiatives are already underway in nursing scholarship, nursing education, and nursing practice, initiatives that will be strengthened by acknowledging a "pedagogy of remembrance" (p. 29) as a way to link the past to the present (Linsley et al., 2019). As a form of educational scholarship, we believe that such pedagogy can assist our profession to learn from its history and craft a more ethical and equitable future for all the members of our profession, as well as for all those whom we serve. 


\section{References}

Adams, L., \& Maykut, C. (2015). Bullying: The antithesis of caring acknowledging the dark side of the nursing profession. International Journal of Caring Sciences, 8(3), 765-773.

Akella, D. (2016). Workplace bullying: Not a manager's right? The Journal of Workplace Rights, 1-10. https://doi.org/10.1177/2158244016629394

Alavi, C., \& Cattoni, J. (1995). Good nurse, bad nurse... Journal of Advanced Nursing, 21, 344 349.

Allan, H., Cowie, H., \& Smith, P. (2009). Overseas nurses' experiences of discrimination: A case of racist bullying? Journal of Nursing Management, 17, 898-906.

Allanson, P. B., Rawlings Lester, R., \& Notar, C. (2015). A history of bullying. International Journal of Education and Social Sciences, 2(12), 31-36.

American Nursing Association. (2015). American Nursing Association position statement on incivility, bullying, and workplace violence. US Professional Issues Panel on Incivility, Bullying, and Workplace Violence.

Báez-León, C., Moreno-Jiménez, B., Aguirre-Camacho, A., \& Olmos, R. (2016). College factors influencing intention to help and helping behaviour in witnesses of bullying in nursing settings. Nursing Inquiry, 23(4). https://doi.org/10.1111/nin.12149

Baltimore, J. J. (2006). Nurse collegiality: Fact or fiction? Nursing Management, 37(5), 28-36.

Bill, L., \& Gillis, L. (2018). Commentary: Indigenous nursing-Learning from the past to strengthen the future of healthcare. Canadian Journal of Nursing Leadership, 31(1), 2831. https://doi.org/10.12927/cjnl.2018.25475

Birks, M., Budden, L., Biedermann, N., Park, T., \& Chapman, Y. (2018). A "rite of passage"? Bullying experiences of nursing students in Australia. Collegian, 25, 45-50.

Bishop, S. R. (2004). Nurses and conflict: Workplace experiences [Unpublished master's thesis]. University of Victoria.

Boland, E. (2007). History versus the past. Poetry Foundation, Poetry of the Day podcast. https://www.poetryfoundation.org/podcasts/74865/history-vs-the-past

Bowllan, N. M. (2015). Nursing students' experience of bullying. Nurse Educator, 40(4), 194198.

Budden, L. M., Birks, M., \& Bagley, T. (2017). Australian nursing students' experience of bullying and/or harassment during clinical placement. Collegian, 24(2), 125-133.

Burnstein, C. J. (1995). Nursing students' perceptions regarding effective interventions used by nurse educators in assisting students to cope with anxiety during the clinical learning experience [Unpublished doctoral dissertation]. University of British Columbia.

Canadian Association of Schools of Nursing. (2012). Ties that bind: The evolution of education for professional nursing in Canada from the 17th to the 21 st century.

Canadian Nurses Association. (2008). Code of ethics for registered nurses. https://www.cnaaiic.ca/-/media/cna/page-content/pdf-en/code_of_ethics_2008_e.pdf 
Canadian Nurses Association. (2017). Code of ethics for registered nurses. https://cnaaiic.ca/ /media/cna/page-content/pdf-en/code-of-ethics-2017-edition-secureinteractive.pdf

Canadian Nurses Association \& Canadian Federation of Nurses Unions. (2015a). Workplace violence and bullying [Joint position statement]. Canadian Nurses Association. https://cna-aiic.ca/ /media/cna/page-content/pdf-en/Workplace-Violence-andBullying_joint-position-statement.pdf

Canadian Nurses Association \& Canadian Federation of Nurses Unions. (2015b). Joint position statement: Practice environments: Maximizing outcomes for clients, nurses and organizations. Canadian Nurses Association.

Clarke, C., Kane, D., Rajacich, D., \& Lafreniere, K. (2012). Bullying in undergraduate clinical education. Journal of Nursing Education, 51(5), 269-276.

Croft, R., \& Cash, P. (2012). Deconstructing contributing factors to bullying and lateral violence in nursing using a postcolonial feminist lens. Contemporary Nurse, 42(2), 226-242.

Darbyshire, P., Thompson, D., \& Watson, R. (2019). Nursing's future? Eat young. Spit out. Repeat. Endlessly. Journal of Nursing Management, 27(7). https://doi.org/10.1111/jonm.12781

Davies, K. (2003). The body and doing gender: the relations between doctors and nurses in hospital work. Sociology of Health and Illness, 25(7), 720-742.

Doane, G. H., \& Varcoe, C. (2013). Relational practice and nursing obligations. In J. Storch, P. Rodney, \& R. Starzomski (Eds.), Toward a moral horizon: Nursing ethics for leadership and practice (2nd ed., pp. 143-159). Pearson-Prentice Hall.

Drees, L. M. (2013). Healing histories: Stories from Canada's Indian hospitals. University of Alberta.

Eggertson, L. (2011). Targeted: The impact of bullying, and what needs to be done to eliminate it. Canadian Nurse, 107(6), 16-20.

Fehr, F. C., \& Seibel, L. M. (2016). Cognitive rehearsal training for upskilling undergraduate nursing students against bullying: A qualitative pilot study. Quality Advancement in Nursing Education, 2(1), Article 5. https://doi.org/10.17483/2368-6669.1058

Flynn, K. (2008). "I'm glad that someone is Telling the nursing story": Writing Black Canadian women's history. Journal of Black Studies, 38(3), 443-460.

Gazza, E. A. (2009). The experience of being a full-time nursing faculty member in a baccalaureate nursing education program. Journal of Professional Nursing, 25(4), 218226.

Gheorghiu, I., Rodrigues, C., \& Ntamwemezi, S. (2014). CSNA position statement on creating an empowering environment for nursing students to eliminate bullying in the nursing profession. Canadian Nursing Students' Association. http://cnsa.ca/wpcontent/uploads/2016/01/Position-statement-2014.pdf 
Gillespie, G., Grubb, P., Brown, K., Boesch, M., \& Ulrich, D. (2017). "Nurses eat their young": A novel bullying educational program for student nurses. Journal of Nursing Education and Practice, 7(7), 11-21. https://doi.org/10.5430/jnep.v7n7P11

Goodwill, J. C. (1989). Indian and Inuit nurses of Canada; profiles. Canadian Woman Studies, 10(2), 117-124.

Griffin, M. (2004). Teaching cognitive rehearsal as a shield for lateral violence: an intervention for newly licensed nurses. Journal of Continuing Education in Nursing, 35(6), 257-263.

Griffin, M., \& Clark, C. (2014). Revisiting cognitive rehearsal as an intervention against incivility and lateral violence in nursing: 10 years later. Journal of Continuing Education in Nursing, 45(12), 535-542.

Hershcovis, M. S. (2011). "Incivility, social undermining, bullying ... oh my!": A call to reconcile constructs within workplace aggression research. Journal of Organizational Behavior, 32(3), 499-519.

Holme, A. (2015). Big ideas: Why history matters to nursing. Nurse Education Today, 35, 635637.

Houshmand, M., O’Reilly, J., Robinson, S., \& Wolff, A. (2012). Escaping bullying: The simultaneous impact of individual and unit-level bullying on turnover intentions. Human Relations, 65(7), 901.

Hunt, C., \& Marini, Z. A. (2012). Incivility in the practice environment: A perspective from clinical nursing teachers. Nurse Education in Practice, 12(6), 366-370.

Hutchinson, M., Wilkes, L., Jackson, D., \& Vickers, M. H. (2010). Integrating individual, work group and organizational factors: Testing a multidimensional model of bullying in the nursing workplace. Journal of Nursing management, 18(2), 173-181.

International Council of Nurses. (2017). Prevention and management of workplace violence. https://www.icn.ch/sites/default/files/inline-

files/PS_C_Prevention_mgmt_workplace_violence_0.pdf

International Council of Nurses. (2019). ICN International workforce forum calls for urgent action from governments to address global nursing shortage. https://www.icn.ch/news/icn-international-workforce-forum-calls-urgent-actiongovernments-address-global-nursing

Jack, K., Hamshire, C., Harris, W. E., Langan, M., Barrett, N., \& Wibberley, C. (2018). “My mentor didn't speak to me for the first four weeks": Perceived unfairness experienced by nursing students in clinical practice settings. Journal of Clinical Nursing, 27(5-6), 929938. https://doi.org/10.1111/jocn.14015

Jackson, D., Hutchinson, M., Everett, B., Mannix, J., Peters, K., Weaver, R., \& Salamonson, Y. (2011). Struggling for legitimacy: Nursing students' stories of organizational aggression, resilience and resistance. Nursing Inquiry, 18(2), 102-110.

Johns, E. (1948). The nurse seeks the university. The Canadian Nurse, 44(9), 720-724.

Keashly, L., Tye-Williams, S., \& Jagatic, K. (2020). By any other name: North American perspectives on workplace bullying. In S. Valvatne Einarsen, H. Hoel, D. Zapf, \& C. L. 
Cooper (Eds.), Bullying and harassment in the workplace: Theory, research and practice (pp. 55-105). CRC Press.

Kenny, N. P., Sherwin, S. B., \& Baylis, F. E. (2010). Revisioning public health ethics: A relational perspective. Canadian Journal of Public Health, 101(1), 9-11.

Linsley, P., Beggs, R., \& McKayc, I. (2019). Contemporary issues: The pedagogy of remembrance: How we remember and learn from the past. Nurse Education in Practice, $82,29-31$.

MacCurtain, S., Murphy, C., O'Sullivan, M., MacMahon, J., \& Turner, T. (2018). To stand back or step in? Exploring the responses of employees who observe workplace bullying. Nursing Inquiry, 25(1), 1-10.

MacKintosh, N., \& Sandall, J. (2010). Overcoming gendered and professional hierarchies in order to facilitate escalation of care in emergency situations: The role of standardised communication protocols. Social Science \& Medicine, 71, 1683-1686.

MacKusick, C., \& Minick, P. (2010). Why are nurses leaving? Findings from an initial qualitative study on nursing attrition. MEDSURG Nursing, 19(6), 335-340.

Martin, D. E., \& Kipling, A. (2006). Factors shaping Aboriginal nursing students' experiences. Nurse Education Today, 26(8), 688-696.

McPherson, K., \& Stuart, M. (1994). Writing nursing history in Canada: Issues and approaches. Canadian Bulletin of Medical History, 11(1), 3-22.

Meissner, J. E. (1986). Nurses: Are we eating our young? Nursing, 16(3), 51-53.

Modibo, N. N. (2004). The shattered dreams of African Canadian nurses. Canadian Woman Studies, 23(2), 111-117.

Neall, A. M., \& Tuckey, M. R. (2014). A methodological review of research on the antecedents and consequences of workplace harassment. Journal of Occupational and Organizational Psychology, 87(2), 225-257.

Nelson, S. (2009). Historical amnesia and its consequences-The need to build histories of practice. Texto Contexto Enferm, Florianópolis, 18(4), 781-787.

Nelson, S., \& Gordon, S. (2004). The rhetoric of rupture: Nursing as a practice with a history? Nursing Outlook, 52(5), 255-261. https://doi.org/10.1016/j.outlook.2004.08.001

O'Flynn-Magee, K., Rodney, P., Pearson, M., Burnay, M., \& Daly, Z. (2020). Interrupting the cycle of bullying witnessed or experienced by nursing students: An ethical and relational action framework. Nurse Education Today, 91, Article 104458. https://doi.org/10.1016/j.nedt.2020.104458

Palaz, S. (2013). Vertical bullying in nursing education: Coping behaviors of Turkish students. International Journal of Nursing Education, 5(1), 193-197.

Prendergast, N. (2014). Multiculturalism policies: Identifying the dialectic of the "ideal type" within the practices of Canadian nursing [Unpublished doctoral dissertation]. University of Toronto.

Randle, J. (2003). Bullying in the nursing profession. Journal of Advanced Nursing, 43(4), 395401. https://doi.org/10.1046/j.1365-2648.2003.02728.x 
Roberts, S. J. (1983). Oppressed group behavior: Implications for nursing. Advances in Nursing Science, 5(4), 21-30.

Seibel, M. (2014). For us or against us? Perceptions of faculty bullying of students during undergraduate nursing education clinical experiences. Nursing Education in Practice, 14(3), 271-274.

Seibel, M., \& Fehr, C. F. (2018). "They can crush you”: Nursing students' experiences of bullying and the role of faculty. Journal of Nursing Education and Practice, 8(6), 66-76.

Small, S. P., English, D., Moran, G., Grainger, P., \& Cashin, G. (2019). "Mutual respect would be a good starting point": Students' perspectives on incivility in nursing education. Canadian Journal of Nursing Research, 51(3), 133-144.

Stanley, D. (2019). A brief history of bullying in nursing: Battles and bullies. JOJ Nurse Health Care, 11(1), Article 555804. https://doi.org/10.19080/JOJNHC.2019.11.555804

Street, A. F. (1992). Inside nursing: A critical ethnography of clinical nursing practice. State University of New York.

Szutenbach, M. P. (2013). Bullying in nursing: Roots, reasons and remedies. Journal of Christian Nursing, 30(1), 16-23.

Tee, S., Üzar Özçetin, Y. S., \& Russell-Westhead, M. (2016). Workplace violence experienced by nursing students: A UK survey. Nurse Education Today, 41, 30-35.

Thomas, C. (2010). Teaching nursing students and newly registered nurses' strategies to deal with violent behaviors in the professional practice. Journal of Continuing Education in Nursing, 41(7), 299-308.

Thomas, S., \& Burk, R. (2009). Junior nursing students' experiences of vertical violence during clinical rotations. Nursing Outlook, 57(4), 226-231.

Varcoe, C., \& Rodney, P. (2002). Constrained agency: The social structure of nurses' work. In B. Singh Bolaria \& H. D. Dickinson (Eds.), Health, illness and health care in Canada (3rd ed., pp. 102-128). Nelson Thomson Learning.

Vessey, J. A., DeMarco, R., \& DiFazio, R. (2011). Bullying, harassment and horizontal violence in the nursing workforce. Annual review of nursing research, 28(1), 133-157.

Vessey, J. A., DeMarco, R. F., Gaffney, D. A., \& Budin, W. C. (2009). Bullying of staff registered nurses in the workplace: A preliminary study for developing personal and organizational strategies for the transformation of hostile to healthy workplace environments. Journal of Professional Nursing, 25(5), 299-306. https://doi.org/10.1016/j.profnurs.2009.01.022

Vukic, A., Jesty, C., Mathews, S. V., \& Etowa, J. (2012). Understanding race and racism in nursing: Insights from Aboriginal nurses. International Scholarly Research Notices, 2012, Article 196437. https://doi.org/10.5402/2012/196437

Weinand, M. R. (2010). Horizontal violence in nursing: History, impact, and solution. The Journal of Chi Eta Phi Sorority, 54(1), 23-26.

Wiskow, C., Albreht, T., \& de Pietro, C. (2010). Policy brief 15: How to create an attractive and supportive environment for health professionals. World Health Organization. 
WorkSafe BC. (2013). Policies for the Workers Compensation Act: Sections relating to bullying and harassment. https://www.worksafebc.com/en/law-policy/occupational-healthsafety/searchable-ohs-regulation/ohs-policies/policies-for-the-workers-compensationact\#SectionNumber:D3-115-2

Wytenbroek, L., \& Vandenberg, H. (2017). Reconsidering nursing's history during Canada 150. Canadian Nurse, 113(4), 16-18. 